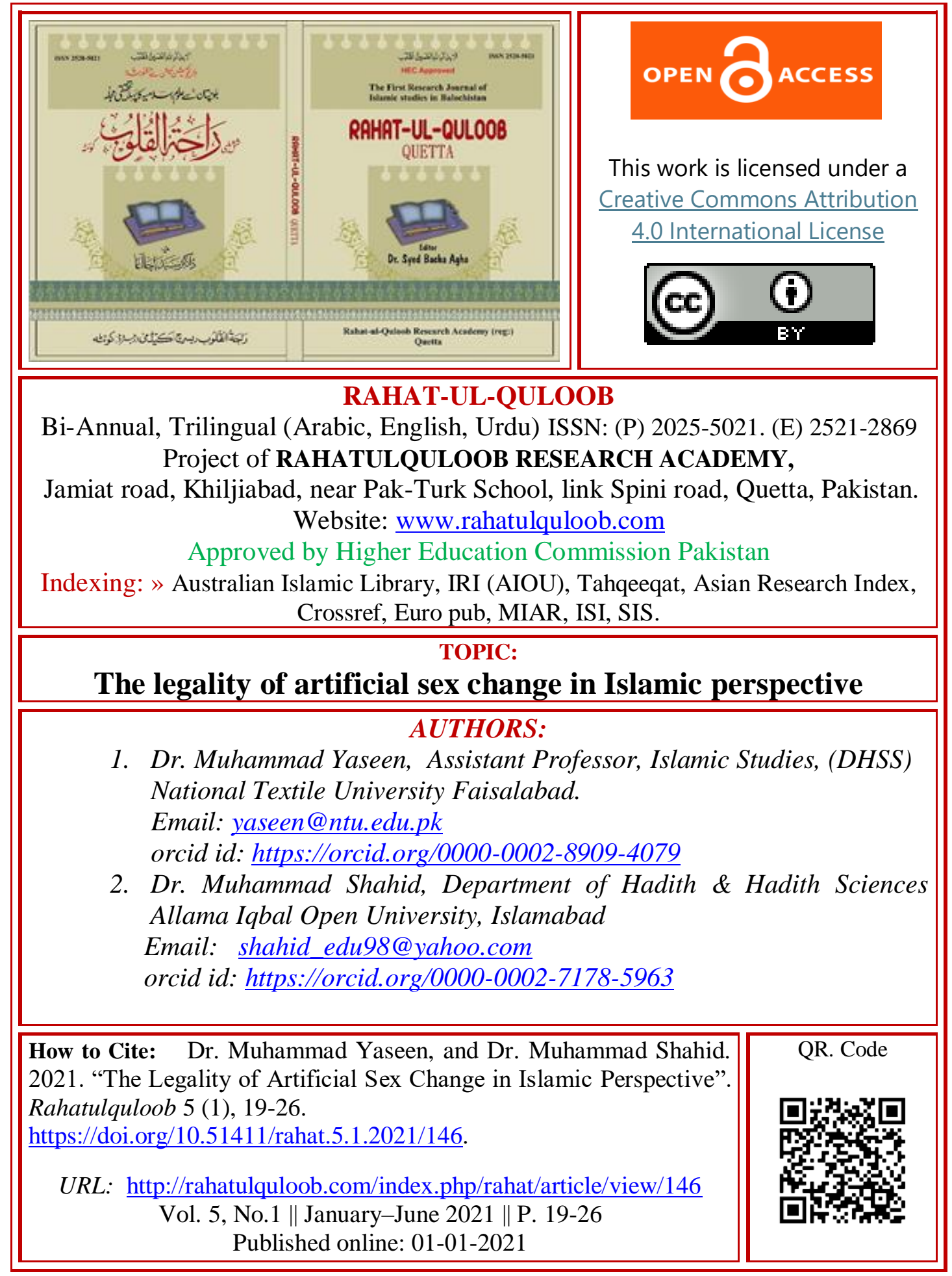




\section{The legality of artificial sex change in Islamic perspective}

\section{ABSTRACT:}

\section{${ }^{1}$ Muhammad Yaseen, ${ }^{2}$ Muhammad Shahid}

Humans and diseases are related to each other since the creation. With the passage of time, humans were able to overcome different diseases. But still, they could not find out the solution for those people who were born in wrong bodies. The progress of medical science ultimately enabled them to restore their originality through corrective surgery or sex reassignment surgery. But soon this was also misused like the other researches by opportunists. The people who were healthy and have developed sexual organs got their sex change artificially without knowing the religious aspects. This article will highlight the Islamic aspects of artificial sex change surgery.

\section{Key Words:}

Change of sex, Gender Change, Hormone therapy. Sex Reassignment Surgery (SRS), FTM Surgery, MTF Surgery

\section{Introduction:}

Initially, every invention is immaculate and used for the welfare of humankind but over time people misused it till it becomes very harmful for human race. The same case is with sex reassignment surgery. In the beginning, it was used as corrective surgery. Later, some opportunists started its usage to accomplish their sexual needs. Now it becomes very easy for normal people to consult a doctor and get their sex change. In Pakistan, this surgery is used as a corrective surgery, but it might be possible soon that some fortune hunters can get benefit from it for their heinous purpose. Therefore, it is necessary to discuss the Islamic ruling to save such people from being astray.

\section{Methodology:}

It is a descriptive study. It highlights the current issue in an analytical way. The data is obtained from different libraries but mostly from electronic media because most of the material is present on it.

\section{Reason for sex reassignment surgery:}

If we try to find out the intentions of the people who have fully developed masculine or feminine organs but still wish to change them with the opposite sex. We find out that in the beginning they were not sexually satisfied by their wives and vice versa, so they found different ways to accomplish their needs. Males inclined to males and females to females. This homosexuality was not tolerable to any society. So, they opted for diverse methods to legitimate their actions. They were successful in passing a bill in their parliament in different westerner countries and even from courts of law that same-sex marriages are legitimate. But still, they were facing disgusting behavior by other people; therefore, they found refuge in changing their sex.

\section{Islamic rulings:}

Islam being a last and comprehensive religion address all aspects of human life. If it does not guide in any mater then its claim of complete religion would be at threat. 
Therefore, it is necessary to find its injunction regarding this modern concept. If one studies Qur'ān he can find that artificial change of sex is a satanic act and a trappe of Satan, who challenged Allāh Almighty when he was expelled from Paradise and was deprived of his the highest status i.e. the leader of the angels because he refused to bow down before Ḥaẓrat Ādam ('alaīh salām).

The Qur'ān says,

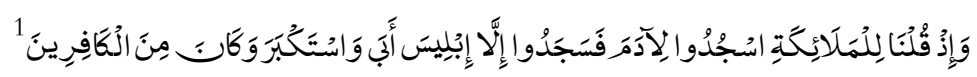

"When We said to the angels, "Bow before Adam", they bowed down, except Iblies. He rebuffed and was egotistical and became of the disbelievers."

So, he was expelled from paradise. At this, he challenged Allāh,

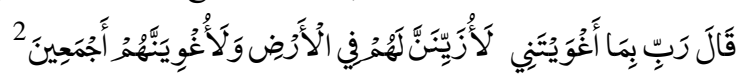

(Iblīes) said, "My Lord, because You have put me in error, I will surely make (disobedience) attractive to them on earth, and I will mislead them all"

Along with it, he also challenged Allāh that he will stimulate the children of Hazrat Adam ('alaīh salām) to change their gender. Qur'ān mentions it in the following words.

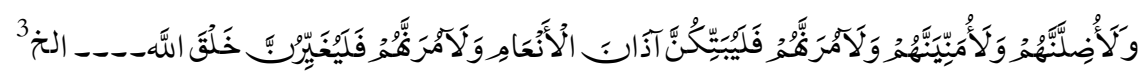

"And I will mislead them, and I will arouse in them (sinful) desire. And I will command them so they will slit the ears of cattle, and I will command them so they will change the creation of Allāh."

Ultimately, he was succeeded in his evil planning and motivated the people to change their sex. It means the one who follows the procedure of changing his/her sex, commits a sin.

Change of sex also leads to homosexuality which is again forbidden according to Qur'ān and Hadīth. The jurists also described its punishments. Qur'ān describes the story of the people of Hazrat Lūṭ ('alaīh salām) in different Āyāt, who were homosexual. For example, in Sūrat Al-'A'rāf Āyāt 80 to 84, Sūrat Ash-Āyāt 5 and 166, Sūrat Hūd Āyāt 69 to 83, Sūrat Al- 'Ankabūt Āyāt 28 to 35, etc. The same theme is also mentioned in "Biblical" (Book of Genesis). ${ }^{4}$ For instance, this Ayat speech too straightforwardly to Rasūl Akram and his followers.

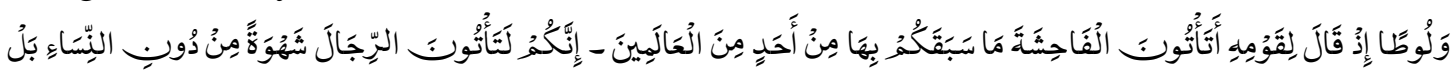

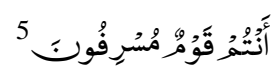

"And Lot said to his people, "Do you commit lewdness such as no people in creation (ever) committed before you? For you practice your lusts on men in preference to women: you are indeed a people transgressing beyond bounds."

In another verse, it has been also pointed out,

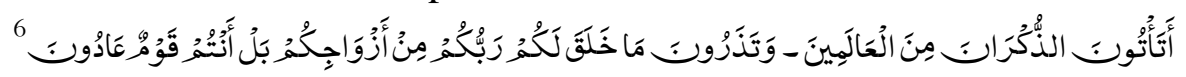


"Do you approach males among the worlds? And leave what your Lord has created for you as mates? But you are a people transgressing."

Qur'ān considered this act worthy of punishment and commands to punish those who commit it. It is said,

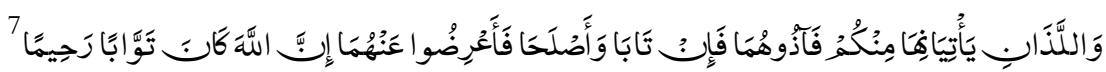

"If two (men) among you are guilty of lewdness, punish them both. If they repent and amend, leave them alone; for Allah is Oft-returning, the Most Merciful."

According to sayings of Rasūl صلى اله عليه وآله وسله homosexuality is Zinā, and be penalized by death. For instance, it is narrated in Abū Dāwūd

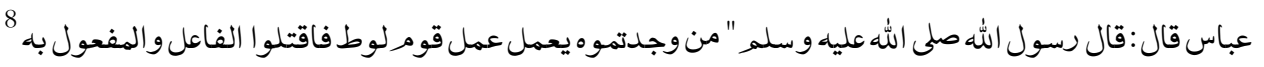

"Narrated 'Abdullāh ibn 'Abbās: The Rasūl Akram( as Lot's people did, kill the one who does it, and the one to whom it is done."9

Sodomy is also forbidden in Islam. The one who commits it will be penalized. Rasūl(w) said regarding it on many places, e.g. he says,

$$
\text { عن ابن عباس في البكريؤخذ على اللوطية قال يرجه } 10
$$

"Narrated 'Abdullāh ibn Abbās: If any unmarried man is found guilty of sodomy, he will be stoned to death ${ }^{11}$ "

Another saying of Rasuly shows that sex change for the cause of homosexuality or sodomy is not permitted in either case. At the same time looking to the private parts of others and lie with the same gender stripped is forbidden by Rasūl . He says,

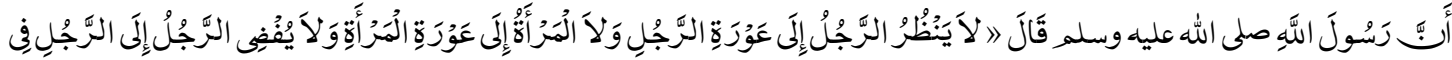

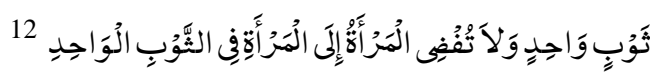

Rasūl(wan said, "A man should not gaze at the private parts of another man and a woman should not look at the private parts of another woman. A man should not lie with another man without wearing lower garment under one cover; and a woman should not lie with another woman without wearing lower garment under one cover"13. By these Qur'ān sayings and Ahadīth, all major Islamic schools condemn homosexuality. ${ }^{14}$ Because unnatural enticement and sensual connections are wrongdoing and lead to sexual activities. Therefore the most jurists believe that there should be a severe punishment to those who commit sodomy or homosexuality, described by the above Qur'ān and Rasūl's sayings, such as stoning to death or whippings, ${ }^{15}$ whereas some scholars differ on the punishment of floggings in case of sodomy (female to female sex). ${ }^{16}$ This punishment was also implemented by the Rightly Guided caliphs. ${ }^{17}$

All the above discussion shows that Islam stops all the possible ways which lead to adultery or fornication. In an article in "Rose al-Yussuf, c'Abd Allah Mubārak anNajjār", a teacher of "Islamic law" at "al-Azhar", argued on the case of Sally, a sex change person in Egypt from a man named Sayyid. He said: "He is subject to penalize 
according to Islam because, he becomes hermaphrodite by himself which is worthy to punish as it can prompt to the hostile wrongdoing of homosexuality, which is the most exceedingly bad wrongdoing in which a common community can get to be distinctly entrapped" 18

According to some fatwas the artificial change of sex is not allowed. For example, when a person asked Prof. Dr. Hayrettin Karaman,

"Is it admissible for a man who is organically and physiologically a man or a female to have an operation and be furnished with a portion of the elements and organs of the inverse sex since he/she feels like an individual from the inverse sex?" He replied,

"It is not religiously passable but rather haram for a man to change his/her sexual orientation because of sex reassignment surgery, which can be called as infringement or degeneration, and afterward to wed. As per that general decision, it is never passable for a man who is organically and physiologically a man or a female to have an operation and be furnished with a portion of the elements and organs of the inverse sex since he/she feels as an individual from the inverse sex and he/she falls into the gloom; it is not respected treatment but rather infringement and degeneration. In this way, the individuals who fall into wretchedness ought to be dealt with by authorities similarly as other individuals who fall into discouragement. If a man has a mental issue and feels that his nose is like a frog and his finger is like a scorpion, no specialist will cut off his nose or finger. A female feels like a female and a man feels like a man. On the off chance that there is a change or deviation in the inclination and enthusiasm for the inverse sex, it is important to credit it to illness, harm, or a turmoil beginning from heredity or instruction, not to the creation; and it is important to search for a cure and treatment since what is not typical is unusual and it should be made strides." 19

This fatwa clearly explained that the disease should be treated rather than making a person impotent. According to another fatwa issued by Sheikh Muhammad Șālih AlMunajjid in 2001 that it is not admissible for a man to change sex from male to female or the other way around. The Muslim must be content with what Allāh has proclaimed. In the meantime, they say that changing one's sex is a sort of altering the formation of Allāh and following the path of the Satan who swore that he would deceive the children of Adam along this way and in others ${ }^{20}$, as Qur'ān says, in 4:119, (mentioned above.)

These individuals who dislike the sex with which they were born and wish that they would be of the other sex, are mentally sick. Therefore, sex reassignment surgery will be haram for such individuals as per all the reliable modern-day scholars. ${ }^{21}$

"Islamic Fiqh Council of the Muslim World League", concluded that it is not passable for either a man whose male organs are full grown or a female whose female organs are full-fledged to change into the other sexual orientation. The endeavor to do as such is a wrongdoing, and its committer should be rebuffed in the light of the changing of the creation of Allah. ${ }^{22}$ AMJA fatwā Committee issued a fatwā when consent was looking for about artificial sex change in 2008. They said, 
"The conversion of this sort is a great crime. It is disfigurement, altering the creation of Allah and imitation of the opposite sex and those who do these things have been cursed by Rasūl ( Hence sex reassignment therapy is an illegal act according to Sharī'ah." 23

According to Hadīthā of Bukhārī (in the chapter of dress), Allāh Almighty cursed such people.

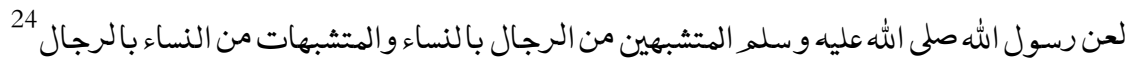

"Rasūl (䤃) reviled the male who impersonates the female and the female who copy the male."

It is narrated by Abū Dāwūd in his book Sunan in the chapter of dress;

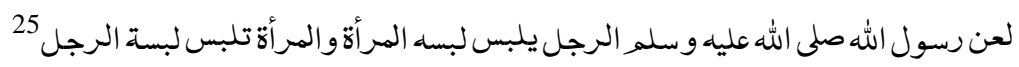

"Narrated by Haẓrat Abū Huraīrah that Allāh cursed the man who wears the dress of a woman and the woman who dress the man."

"The senior Ulama Council in Saudi Arabia" provides the following recommendation. "A sex-change operation (i.e., converting someone with a completely developed gender to the opposite sex) is prohibited, and it is even regarded crime per Qur'ān and Rasūl's sayings." 26

In the end, we conclude the point of view by the arguments of the scholars who are in favor of sex change and those who are against it.

The scholars who are in its favor express, "To adjust the gender, sex change procedure might be acceptable as a medical intervention. Firstly, it's illegitimate but allowable on the justification of the grim necessity of transsexuals by this famous max i m, "Necessity overrules forbidding. ${ }^{27}$ "Besides, it doesn't stretch out to altering with Allāh's inborn nature. However, it is a solution for a transsexual's physical disorder" 28 e.g. when a particular child is 3 years old, he starts showing the feelings of converse gender, as he was born in the wrong body. It is a natural deformation and needs sex change operation because other treatments do not work, so it must be permitted; as a matter of first importance, it is not to changing of one's intrinsic nature but rather is the corrective step of inappropriate things of a person. It is like the validity of going through the operation to change the malfunctioned organ of the individual. Therefore, it cannot be considered altering the nature of a person.

Whereas on the other hand, the jurists who oppose artificial sex change, prohibited it under the following grounds:

1. It is the act of changing Allāh's creation and is definite a primal sinful act of the devil, ${ }^{29}$

2. The basic purpose of this conversion is the changing of one's societal sexual part made by Allāh with the opposite, subsequently, ultra-disease refused by the prophet (PBUH) on womanish and mannishness, alluded recently.

3. It is, for the most part, finished with the motivation behind disguising 
one`s certifiable identity consequently, it is a sort of misdirection which is Haram by this Rasūl

"Anybody who cheats does not belong to us."

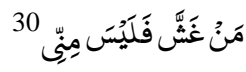

4. Its surgical procedure includes amputating one organ to substitute it with a superficial one, which is parallel to disfigurement and was declared illegal by the Rasūl ${ }^{31}$

5. It is not just superfluous from a medicinal perspective, as it turns not for a therapeutic reason but rather restorative inspiration, it likewise involves post-surgery or hormonal treatment complexities, in this way it is disallowed in Shari'ah. Above all, the individual doing it thinks that it's difficult to be socially acknowledged by other Muslims as a result, it put him in constant psychological stress.

In short, if one seeks sex change surgery to correct his gender and to spend a normal life in society it is allowed. On the other hand, if a person with fully developed organs change his sex only to fulfill his sexual desire, it cannot be allowed in any case. In the first situation, the trustworthy doctor must recommend for the surgery as a last resort.

\section{Conclusion:}

Sex change through surgery although plays a vital role in the lives of the transsexuals by restoring their original identification and filled their withered faces and hearts with smile and hope. Some people, however, use it to change their healthy organs to opposite genders only to satisfy their inner. This leads to indecency. The homosexuals and sodomists get a chance to legalize their activities under the cover of gender change. This promotes adultery in society. Although artificial sex change does not convert one person fully to the opposite gender because the internal parts cannot be implanted. The external parts also cannot actively work like healthy people. The converted man from a woman cannot impregnate the converted woman or healthy woman as he does not have the ability of ejaculation and the same case would be vice versa. Therefore; their marriages would be considered as the marriage with the same sex which is liable to punishment according to the Shari'ah yet, it enable them to have a physique like a normal person. They can get jobs easily. If they are not able to get children, they can think that many normal couples are there who are childless. So, it is allowed as corrective measures. On the other hand, artificial sex change causes several unethical issues which a not allowed in any civilized society. 


\section{References}

${ }^{1}$ Al-Quran 2:34

${ }^{2}$ Al-Quran 15:39

${ }^{3}$ Al-Quran 4:119

${ }^{4}$ Michaelson, Jay God vs Gay? The Religious Case for Equality. Boston: Beacon Press, 2011, pp68-69 ISBN 9780807001592.

${ }^{5}$ Al-Quran 7:80-81

${ }^{6} \mathrm{Al}-\mathrm{Quran}$ 26:165-166

${ }^{7} \mathrm{Al}-\mathrm{Quran}$ 4:16

${ }^{8}$ Abū Dāwūd, Sulaymān b. al-Ash ‘ath, Al-Sunan, Riyād: Dār al-Salām, 1999, -4462.

${ }^{9}$ Aḥmad Hasan (Translator), Sunan Abū Dāwūd, (English Translation), Sh.M.Ashraf, Lahore, 1984

${ }^{10} A b u ̄$ Dāwūd, Sulaymān b. al-Ash ‘ath, Al-Sunan, Riyād: Dār al-Salām, 1999, -4463.

${ }^{11}$ Aḥmad Hasan (Translator), Sunan Abū Dāwād, (English Translation), Sh.M.Ashraf, Lahore, 1984

${ }^{12}$ Muslim, Ibn al-Hajj āj b. Muslim, al-Jāmi al-Ṣahịh, Riyād: Dār al-Salām 2007-794

${ }^{13}$ Muḥammad Āmīn and Abū Usāmah al- 'arabī bin Razdūq (English Translators) Riyā as-Sāliḥīen, Riyād: Dār al-Salām, n.d

${ }^{14}$ Muḥammad Sāliḥ al-Munajjid. "Why does Islam forbid lesbianism and homosexuality?". Islamqa.info. Retrieved 9 May, 2015

${ }^{15} \mathrm{ibd}$

${ }^{16} \mathrm{Ibd}$ "The punishment for homosexuality". Islamqa.info. Retrieved 9 May 2015.

${ }^{17}$ Mūsā, Ibrahīm. "Encyclopedia of Islam and the Muslim World" Macmillan Reference USA.

${ }^{18}$ Rowson, Everett. "Encyclopedia of Islam and the Muslim World". Macmillan Reference USA. Retrieved 1 May 2013

${ }^{19}$ The boy Sally is an artificial female, 'Abd Allāh Mubarak an-Najjār, Rose al-Yūsuf, April 11, 1988, pp. 28-29.

${ }^{20} \mathrm{http}$ //www.questionsonislam.com/question/it-permissible-person-who-biologically-andphysiologically-man-or-woman-have-operation-and- , 2010.

${ }^{21}$ Muḥammed Șāliḥ al-Munajjid , 2001 (Fatwā 21277), http://islamqa.info/en/21277.

${ }^{22} \mathrm{Ibd}, 2004$ (Fatwā 34553) http://islamqa.info/en/34553.

${ }^{23}$ Islamic Fiqh Council of the Muslim World League Decision No. 5, Session 11, 1989, http://en. themwl.org

${ }^{24}$ al-Bukhari, Muhammad b. Ismā‘îl Abū 'Abd Allāh, aL-Jāmi` al-Ṣaḥịh, Riyād: Dār al-Salām, 19995546

${ }^{25}$ Abū Dāwūd, Sulaymān b. al-Ash'ath, Al-Sunan, Riyād: Dār al-Salām, 1999, -4098

${ }^{26}$ Consensus statement on intersex issues: No. 176. Saudi Arabia: The Senior Ulama Council, 1992. https://www.ncbi.nlm.nih.gov/pmc/articles/PMC3216232/

${ }^{27}$ Fayṣal Mawlawi, accessed on May 14, 2011 from www.malawi.net.

${ }^{28}$ ibd

${ }^{29}$ Changing One's Gender from an Islamic Perspective, https://archive.islamonline.net/?p=6393

${ }^{30}$ Muslim, Ibn al-Hajj āj b. Muslim, al-Jāmi al-Ṣahịḥ, Riyād: Dār al-Salām 2007-295

${ }^{31}$ Ibn Mājāh, Moḥammad b. Yazīd, Al-Sunan, Pustaka 'iz̄ām, 2005, 2:23

${ }^{32}$ al-Bukhari, Muḥammad b. Ismā'īl Abū 'Abd Allāh, aL-Jāmi' al-Ṣaḥịh, Beruit: Dār al-Fikr, n.d), 936 